\title{
Occurrence of Pyemotes sp. on Tuta absoluta (Meyrick)
}

\author{
Carlos Romero Ferreira de Oliveira ${ }^{1}$, Cláudia Helena Cysneiros Matos ${ }^{2,3}$ and Eduardo \\ Hatano $^{2,4}$ \\ ${ }^{1}$ Unidade Acadêmica de Serra Talhada; Universidade Federal Rural de Pernambuco; 56900-000; \\ romero@uast.ufrpe.br; Serra Talhada - PE - Brasil. ${ }^{2}$ Unidade Acadêmica de Serra Talhada; Universidade Federal \\ Rural de Pernambuco; 56900-000; Serra Talhada - PE - Brasil. ${ }^{3}$ Departamento de Biologia Animal-Entomologia; \\ Universidade Federal de Viçosa; 36570-000; ccysne@hotmail.com; Viçosa - MG - Brasil. ${ }^{4}$ Ecological Chemistry \\ Laboratory; Faculty of Agriculture; Hokkaido University; 060-8589; e-hatano@abs.agr.hokudai.ac.jp; Sapporo - \\ Japan
}

\begin{abstract}
The aim of this work was to study the population reduction of the tomato leafminer moth, Tuta absoluta (Meyrick), by Pyemotes sp. in the laboratory. The mite became greenish when fed on caterpillars, pupae, and adults of T. absoluta. The caterpillars and adults of $\mathrm{T}$. absoluta were quickly paralyzed by the mite venom. A single T. absoluta could host many Pyemotes sp, physogastric females, which were allowed to grow on the moth. Pyemotes sp. can be a new alternative for the biological control of T. absoluta. However, this possibility must be better understood before it could be recommended, because Pyemotes sp. could also cause dermatitis in the humans.
\end{abstract}

Key words: Mite, parasitism, tomato leafminer, biological control

\section{INTRODUCTION}

The mite Pyemotes tritici (Lagréze-Fossat and Montagné) (Acari: Pyemotidae) has many relevant characteristics for the biological control, such as short life cycle, a wide range of hosts, and rapid population growth (Moser et al., 1971; Bruce and Lecato 1979; Bruce and Wrensch 1990). Two other aspects of the Pyemotes spp. are important: their physogastric process and the suppression of their immature stages. During the feeding period, enlargement of the female body occurs and the same time, multiple embryos are produced and incubated (Gerson and Smiley 1990). The latter contributes to shorten the mite life cycle, by the suppression of the nymphal stages (Evans 1992). New adults are born from the female body. Females begin foraging their quarry soon after the fecundation. They can tightly attach to the host body and paralyze it, by injecting venom (toxins). Pyemotes spp. is also known as "straw-itch mite" and its venom can also injure the humans, causing dermatitis (Moser 1975). In addition, the venom of the female can paralyze an insect host (Tomalski et al., 1988) even when it is immature for reproduction (Bruce and Wrensch 1990). Mite generalist behavior and efficient killing are strong points to be considered for a promising biological control strategy.

Many studies have been carried out on Pyemotes spp. biology (Moser 1975; Bruce and Lecato 1980; Bruce 1983; Bruce and Wrensch 1990). Due to its short life cycle, the population of Pyemotes sp. can easily increase. According to Tomalski et al. (1988) and Hoschele and Tanigoshi (1993), 200 to 350 sexually mature mites are produced per

\footnotetext{
${ }^{*}$ Author for correspondence
} 
female. More than 100 insect species among the Coleoptera, Hymenoptera, Lepidoptera, Homoptera, Strepspitera, and Diptera have been described as P. tritici hosts (Cross et al., 1975; Bruce and Lecato 1980; Bruce and Wrensch 1990). In most cases, the mite was found on mass rearing in the laboratories and stored grains, attacking larvae of Plodia interpunctella (Hübner) (Lepidoptera: Pyralidae), Ephestia cautella (Walker) (Lepidoptera: Pyralidae), Oryzaephilus mercator (Fauvel) (Coleoptera: Silvanidae), Lasioderma serricorne (Fabricius) (Coleoptera: Anobiidae), and adults of Tribolium castaneum (Herbst) (Coleoptera: Tenebrionidae) and Sitotroga cerealella (Oliver) (Lepidoptera: Gelechiidae) (Bruce and Lecato 1979; Bruce and Lecato 1980; Hoschele and Tanigoshi 1993).

In October 2001, high mortality among larvae of Tuta absoluta (Meyrick) (Lepidoptera: Gelechiidae) at different stages was observed in a mass rearing kept at the Integrated Pest Management Laboratory (Animal Biology Department/ Entomology - Federal University of Viçosa, Brazil). After the careful analysis, it was concluded that the high mortality rate was due to the increase in the population and parasitism of Pyemotes sp. on the insect. All the collected mite specimens were identified as Pyemotes sp., ventricosus group (Cross and Moser, 1975; Cross et al., 1981).
T. absoluta, known as tomato leafminer moth, is the main tomato pest in Brazil and other South American countries because it is hard to be controlled (Imenes et al., 1990; Castelo Branco 1992; Gonçalves-Gervásio et al., 1999). The leafminer can attack the whole plant at all the growing stages by opening galleries in leaves, branches, buds, and fruits (Fernandez and Montagne 1990; Souza et al., 1992; UchôaFernandes et al., 1995). During Pyemotes sp. was feeding on caterpillars (Fig. 1), pupae (Fig. 2) and adults (Fig. 3) of T. absoluta, with one or more mites per host (Figs. 1, 2 and 3), was observed that soon after the parasitic mite attachment, toxins paralyzed the larvae and adults. At that point, mites became greenish (Fig. 4), turning yellowish and then brownish during the feeding. The opisthosoma of Pyemotes sp. also changed and the female body enlarged, becoming spherical and milky (physogastric process).

In agreement with Trivelli and Velásquez (1985), $P$. tritici is lethal for mass rearing of insects because the mite can kill a whole insect population, as found in study. Therefore, Pyemotes sp. can be considered a strong biological control agent for $T$. absoluta, showing fast reproduction and efficient parasitism over the insect. However, because Pyemotes sp. can cause dermatitis in humans, further studies must be conducted on the mite field behavior and performance, which remain unknown.

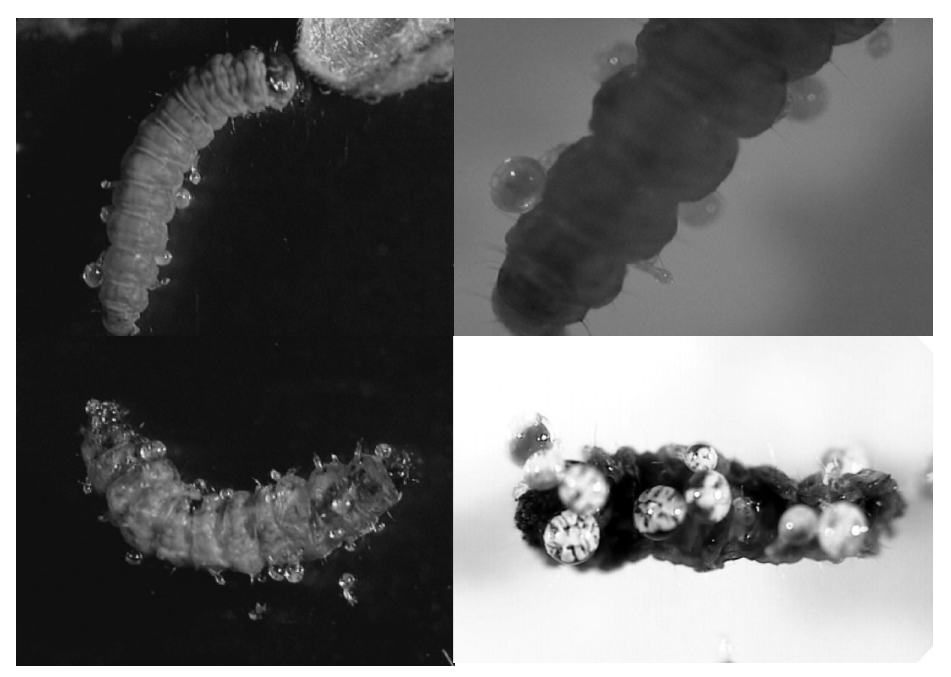

Figure 1- T. absoluta larvae attacked by physogastric females of Pyemotes sp 


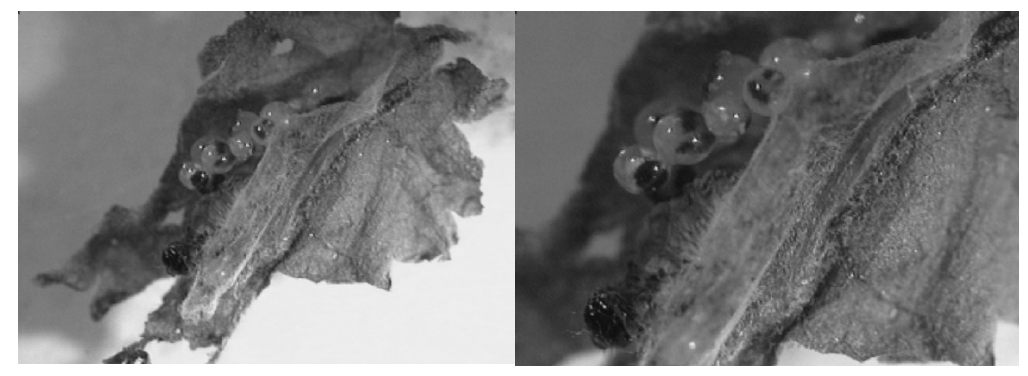

Figure 2- Pyemotes sp. physogastric females on T. absoluta pupae

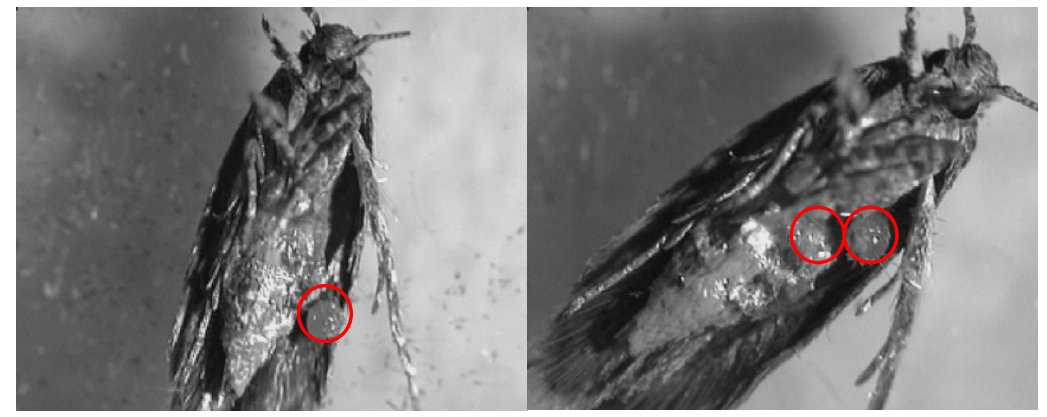

Figure 3- Pyemotes sp. physogastric females on T. absoluta adults

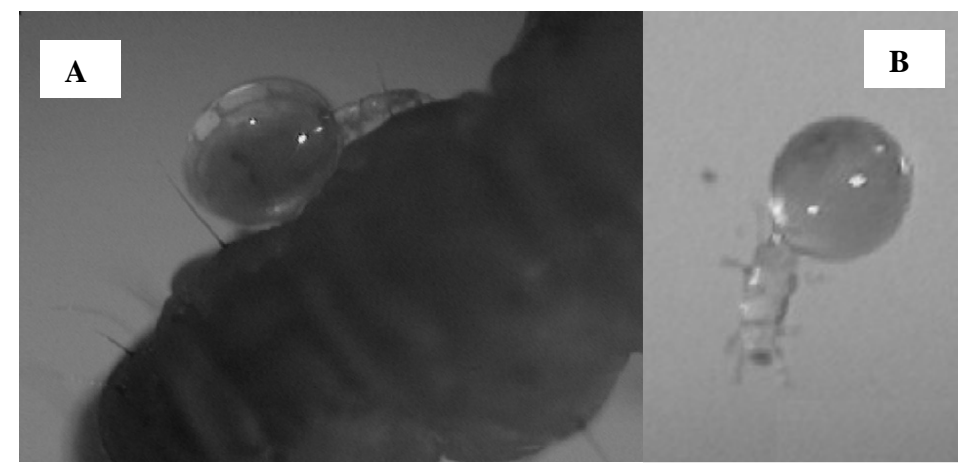

Figure 4 - A) A Pyemotes sp. physogastric female feeding on a T. absoluta caterpillar; B) Greenish colour of Pyemotes sp. physogastric female after eating.

\section{RESUMO}

O ácaro Pyemotes sp. (Acari: Pyemotidae) é um parasita de várias espécies de insetos e exibe o processo de fisogastria na reprodução. É registrada a ocorrência de Pyemotes sp. sobre a traça-dotomateiro, Tuta absoluta (Meyrick), que sofreu redução considerável de suas populações em condições de laboratório. Este ácaro foi observado parasitando larvas, pupas e adultos de T. absoluta 
e suas fêmeas fisogástricas apresentaram coloração esverdeada. As larvas e adultos de T. absoluta atacados por Pyemotes sp. exibiram paralisia em poucos minutos, devido à injeção de toxinas por parte do ácaro. Observou-se que um único indivíduo de $T$. absoluta pode suportar muitas fêmeas fisogástricas de Pyemotes sp., permitindo que outra geração do ácaro continuasse a se reproduzir. O ácaro Pyemotes sp. surge como uma possibilidade para o controle biológico de $T$. absoluta, mas sua utilização deve ser melhor avaliada já que é uma espécie causadora de dermatites em humanos.

\section{REFERENCES}

Bruce, W. A. (1983), Mites as biological control agents of stored product pests. In- Biological control of pests of mites, eds. M.A. Hoy, L. Knutson and G.L. Cunningham. Berkeley, University of California, pp. 74-78.

Bruce, W. A. and Lecato, G. L. (1979), Pyemotes tritici: potential biological control agent of stored product insects. Rec. Adv. Acarol., 1, 213-220.

Bruce, W. A. and Lecato, G. L. (1980), Pyemotes tritici: a potential new agent for biological control of the red imported fire ant, Solenopsis invicta (Acari: Pyemotidae). Intern. J. Acarol., 6, 271-274.

Bruce, W. A. and Wrensch, D. L. (1990), Reproductive potential, sex ratio, and mating efficiency of the straw itch mite (Acari: Pyemotidae). J. Econ. Entomol., 83, 384-391.

Castelo Branco, M (1992), Flutuação populacional da traça-do-tomateiro no Distrito Federal. Hort. Bras., 10, 33-34.

Cross, E. A. and Moser, J. C. (1975), A new dimorphic species of Pyemotes and a key to previouslydescribed forms (Acarina: Tarsonemoidea). Annals Entomol. Soc. America, 68, 723- 732.

Cross, W. H.; McGovern, H. W. and Cross, E. A. (1975), Insect hosts of parasitic mites called Pyemotes ventricosus (Newport). J. Ga. Entomol. Soc., 10, 1-8.

Cross, W. H.; Moser, J. C. and Rack, G. (1981), Some new forms of Pyemotes (Acarina: Pyemotidae) from forest insects, with remarks on polymophism. Internat. J. Acarol.,7, 179-196.

Evans, G. O. (1992), Principles of Acarology. CAB International. Wallingford, Oxon, UK. 563 p.

Fernandez, S. and Montagne A. (1990), A biologia del minador del tomate, Scrobipalpula absoluta (Meyrick) (Lepidoptera: Gelechiidae). Bol. Entomol. Venezuelana, 5, 89-99.
Gerson, U. and Smiley, R. L. (1990), Acarine biocontrol agents: an illustrated key and manual. Chapman and Hall, New York. 174p.

Gonçalves-Gervásio, R. C. R.; Ciociola A. I.; SantaCecília, L. V. C. and Maluf, W. R. (1999), Aspectos biológicos de Tuta absoluta (Meyrick, 1917) (Lepidoptera: Gelechiidae) em dois genótipos de tomateiro contrastantes quanto ao teor de 2tridecanona nos folíolos. Ciênc. Agrotec., 23, 247251.

Hoschele, W. and Tanigoshi, L. K. (1993), Pyemotes tritici (Acari: Pyemotidae), a potential biological control agent of Anagasta kuehniella (Lepidoptera: Pyralidae). Exp. Appl. Acarol., 17, 781-792.

Imenes, S. D. L.; Uchoa-Fernandes, M. A.; Campos, T.B. and Takematsu, A. P. (1990), Aspectos biológicos e comportamentais da traça-do-tomateiro Scrobipalpula absoluta (Meyrick, 1917) (Lepidoptera: Gelechiidae). Arq. Inst. Biol., 57, 6368.

Moser, J. C.; Cross, E. A. and Roton, L. M. (1971), Biology of Pyemotes parviscolyti (Acarina: Pyemotidae). Entomophaga, 16, 367-379.

Moser, J. C. (1975), Biosystematic of the straw itch mite with special reference to nomenclature and dermatology. Trans. R. Entomol. Soc. London, 127, 185-191.

Souza, J. C. de; Reis, P. R. and Salgado, L. O. (1992), Traça-do-tomateiro, histórico, reconhecimento, biologia, prejuízos e controle. Boletim técnico, Belo Horizonte, EPAMIG, 38, 19p.

Tomalski, M. D.; Bruce, W. A.; Travis, J. and Blum, M.S. (1988), Preliminary characterization of toxins from the straw itch mite, Pyemotes tritici, which induce paralysis in the larvae of a moth. Toxicon., 26, 127-132.

Trivelli, H. Dell'O. and Velásquez, C. J. A. (1985), Insectos que dañan granos y productos almacenados. Oficina Regional de la FAO para América Latina y el Caribe, Santiago, 142p.

Uchôa-Fernandes, M. A.; Della Lucia, T. M. C and Vilela, E. F. (1995), Mating, oviposition and pupation of Scrobipalpuloides absoluta (Meyr.) (Lepidoptera: Gelechiidae). An. Soc. Entomol. Bras., 24, 159-164.

Received: December 26, 2005; Revised: September 28, 2006; Accepted: May 24, 2007. 